\title{
Usefulness of capsule endoscopy in patients with suspected small bowel disease
}

\author{
A. Caunedo, M. Rodríguez-Téllez, J. M. García-Montes, B. J. Gómez-Rodríguez, J. Guerrero', \\ J. M. Herrerías Jr., F. Pellicer and J. M. Herrerías
}

Department of Gastroenterology. University Hospital Virgen Macarena. Seville, Spain. ${ }^{1}$ Unidad de Aparato Digestivo. Hospital Civil del INSALUD. Ceuta, Spain

\begin{abstract}
Aim: to study the usefulness and safety of capsule endoscopy as a diagnostic tool in various small bowel disorders.

Design: a retrospective analysis of a series of cases.

Material and methods: between August 2001 and August 2002, 92 capsule endoscopy procedures were performed in 88 patients $(53 \mathrm{M} / 39 \mathrm{~F}$, age: $43.87 \pm 16.78)$. Indications included: chronic diarrhea $(n=33)$; unknown abdominal pain $(n=29)$; occult gastrointestinal bleeding or iron-deficiency anemia ( $\mathrm{n}=$ 13); abdominal discomfort in NSAID takers $(n=7)$; staging of gastrointestinal tumors $(n=4)$, and asymptomatic controls $(n=$ 2). Previously performed gastroscopy, colonoscopy, and smallbowel follow-through were not conclusive in all patients.

Results: most frequently relevant findings included: jejunoileal apthas and ulcerations (29 patients), vascular malformations (13 patients), and intestinal neoplasm (6 patients). The groups with a higher rate of findings related to this indication were occult gastrointestinal bleeding (76.92\%) and chronic diarrhea (67.85\%), with the lowest rate in the abdominal pain group (34.48\%). Therapeutic strategy was directly changed in 36 of 88 patients (40.90\%) because of capsule-endoscopic findings. The only observed complication was the failed excretion of one of the capsules because of an unknown ulcerated intestinal stricture.

Conclusions: capsule endoscopy is a safe procedure which can study the entire small bowel, meaning a valuable tool for the management of patients with suggestive signs and symptoms of intestinal disorders.
\end{abstract}

Key words: Capsule endoscopy. Occult gastrointestinal bleeding. Enteroscopy. Enteroclysis. Chronic diarrhea. Abdominal pain.

Recibido: 27-01-03.

Aceptado: 29-07-03.

Correspondencia: Juan M. Herrerías. Servicio de Aparato Digestivo ( $8^{\mathrm{a}}$ planta). Hospital Universitario Virgen Macarena. Avda. Dr. Fedriani, s/n. 41071 Sevilla. Tel.: 955 008801. Fax: 955 008805. e-mail: jmherrerias@ @upercable.es
Caunedo A, Rodríguez-Téllez M, García-Montes JM, GómezRodríguez BJ, Guerrero J, Herrerías JM Jr, Pellicer F, Herrerías $J M$. Usefulness of capsule endoscopy in patients with suspected small bowel disease. Rev Esp Enferm Dig 2004; 96: 10-21.

\section{INTRODUCTION}

Since the inception of endoscopic examinations, physicians have wanted to directly visualize the entire digestive tract, but the endoscopic examination of the small bowel remained elusive because of its long length and complex, looped configuration. Small bowel followthrough, the most commonly used exploration, is not able to demonstrate flat lesions such as angiodysplasia or small mucosal lesions (1). Enteroclysis has been reported to be more accurate than small bowel follow-through, but this difference does not seem to be very significant in comparison with a well-performed barium followthrough $(2,3)$. Additionally, enteroclysis requires a skilled radiologist, causes pain and discomfort, needs sedation, involves more patient radiation, and is expensive and time-consuming (1-3).

Push enteroscopy (PE) may diagnose subtle mucosal lesions, take biopsies, and perform therapeutic procedures, but only reaches a limited part of the small bowel, usually between 50 and $120 \mathrm{~cm}$ of the upper jejunum (46 ). In addition, the technique is only available at specialized centers, is uncomfortable for the patient, has to be performed with deep sedation, its results strongly depend on the experience of the endoscopist, and complications appear more often than in upper endoscopy, particularly when an overtube is used (4-6). Sonde enteroscopy has been performed for several years to reach deeper areas of the small bowel. Even with this method a complete enteroscopy was mostly not possible, and several parts of the 
mucosa were not visible due to uncontrolled movements of the endoscope (7). This technique is also uncomfortable or painful, very time-consuming, and unable to take biopsy samples, and therapeutic interventions are not possible; so the use of this procedure has largely been abandoned. Intraoperative endoscopy, although used with great success, is more invasive and associated with a higher rate of complications (8).

Advances in robotics and miniaturization have recently allowed to develop wireless capsule endoscopy (CE), a small device that may be swallowed by the patient and, in a painless and non-invasive way, provides images of the entire small bowel (9-11). The aim of this study was to expose our one-year experience with the capsule, as well as to analyze the usefulness of wireless endoscopy as a diagnostic tool in different small bowel disorders.

\section{PATIENTS AND METHODS}

Patients: from August 30, 2001 to August 30, 2002, 92 capsule endoscopies were performed in 88 patients with various digestive signs and symptoms. Thirty-nine patients were female and 53 male, with an average age of $43.87 \pm 16.78$ (8-74) years. Indications for CE included: chronic diarrhea (group 1: 33 patients); unexplained abdominal pain (group 2: 29 patients); obscure gastrointestinal bleeding (OGB), and iron-deficiency anemia (group 3: 13 patients); abdominal discomfort in NSAID-takers (group 4: 7 patients); staging for gastrointestinal tumors (group 5: 4 patients); and asymptomatic controls (group 6: 2 patients) (Table I). The seven patients in group 4 are participating in another, yet unfinished trial that studies gastrointestinal damage as induced by NSAIDs.

All patients had previously undergone gastroscopy and colonoscopy, whose findings had not been conclusive. A small bowel follow-through was performed in all patients where stenotic lesions had been ruled out. Contraindications for the M2A capsule included patients with suspected or documented intestinal obstruction or strictures, patients who could not swallow the capsule, patients who were nonsurgical candidates or who refused to entertain the idea of surgery in case of device-induced obstruction, patients with a pacemaker or other implanted electrome-

Table I. Epidemiological characteristics of patients explored by capsule endoscopy according to indication

\begin{tabular}{lrrc}
\hline & $n$ & Women & Age \\
\hline Chronic diarrhea & 33 & 11 & $36.19 \pm 17.41$ \\
Unexplained abdominal pain & 29 & 13 & $47.24 \pm 13.72$ \\
Obscure Gl bleeding & 13 & 7 & $49.54 \pm 22.99$ \\
Dyspepsia in NSAID takers & 7 & 7 & $50.8 \pm 13.01$ \\
Staging for Gl tumor & 4 & 1 & $48.67 \pm 7.94$ \\
Healthy controls & 2 & 0 & $55.5 \pm 2.12$ \\
All subjetcs & 88 & 39 & $43.87 \pm 16.78$ \\
\hline Gl: gastrointestinal. & & &
\end{tabular}

dical devices, and pregnant women. An informed consent was obtained in all cases before the technique was carried out.

Method: we used an endocopic capsule of 11 x $26 \mathrm{~mm}$ $\left(\mathrm{M} 2 \mathrm{~A}^{\mathrm{TM}}\right.$ Given Imaging ${ }^{\circledR}$, Yoqneam, Israel) in size that contains a colour camera chip that can take two photographs per second, a white light source, a short focal distance lens, an UHF radio frequency transmitter, an antenna, and two batteries. The displacement of the device through the gut follows the physiological gastrointestinal peristaltic movements and needs no air insufflation. Following a pre-established scheme, we placed eight external sensors on the abdominal wall to collect all the photographs and tape them in a Holter system that the patient carries in a belt. The patient must carry this system during seven-eight hours and does not need to be hospitalised. Once the test is finished, the images collected by the Holter are processed in a computer, where they may be selected and analyzed in detail using a specific software $\left(\right.$ RAPID $\left.^{\mathrm{TM}}\right)$.

Technique: patients must abstain from food and drinks for at least 8 hours before capsule endoscopy. Medications were taken not less than 8 hours before procedure onset. Drugs that could delay gastric emptying were avoided until capsule endoscopy was completed. The eight sensor arrays were attached to the abdomen in their correct locations, and the recorder-battery belt was placed around the patient's waist. After removing the capsule from its blister pack and cheking that the blue light in the data recorder kept on blinking, the capsule was swallowed by the patient with a glass of water. The patient was allowed to go home and advised to neither eat nor drink for 2 hours. The patient could drink liquids after 2 hours and have a light snack after 4 hours. All patients were told to contact immediately their physician in case of abdominal pain or discomfort, vomiting or nausea during the procedure. They were advised not to stay near any powerful electromagnetic field source (like magnetic resonance devices) until the capsule was excreted. Patients returned after 8 hours, the equipment was removed, and the recorder was connected to the workstation, in which images were processed and then viewed in a monitor using the RAPID ${ }^{\mathrm{TM}}$ software. This allows images to be viewed at various speeds, with facilities for pausing and rewinding.

Statistical analysis: the results are shown in percentages or average value \pm standard deviation, according to each case.

\section{RESULTS}

Capsule endoscopy could be carried out in all 88 patients in the study. In four cases the exploration was repeated. Two patients with gastrointestinal neoplasm (intestinal lymphoma and gastrointestinal stromal tumor) were reviewed after specific therapy (chemotherapy and surgery, 
respectively). In one patient with obscure gastrointestinal bleeding and delayed gastric emptying, the capsule remained in the stomach 8 hours after ingestion and was excreted five days later. Thus, another CE with the administration of a prokinetic agent was performed 8 days later, and the entire small bowel could be studied. In another case, CE did not transmit images since it reached the stomach. Another CE was performed the following day without any technical problem.

Capsule endoscopy was normal in 11 patients. The most frequent findings were those suggestive of Crohn's disease (focal villous denudation, fissures, ulcerations and aphtas) in 29 patients (Fig. 1), vascular malformations (angiodysplasia, angiomas) in 8 patients (Fig. 2), small bowel neoplasms (polyps, lymphomas, GIST tumor) in 6 cases (Fig. 3), lesions suggestive of intestinal damage caused by NSAIDs (erosions, ulcers, strictures) in 6 patients, lymphoid nodular hyperplasia (3 patients), lymphangiectasia or small chylomas (10 patients), and congestive enteropathy (1 patient). Gastroduodenal erosions or small ulcers were observed in 8 patients, which were previously demonstrated by gastroscopy in 4 cases. The other 4 patients (all of them with OGB) were diagnosed by CE. Subtle intestinal lesions (edema, slight denudations or focal erythema) were considered a nonspecific enteropathy. Other findings detected in a previous gastroscopy were lesions suggestive of peptic esophagitis (n $=25)$, esophageal varices $(n=1)$, non-erosive gastritis and duodenitis $(n=35)$, and congestive gastropathy $(n=$ 3 ). The groups with a higher rate of positive findings (defined as findings potentially related to the indication) were OGB (84.6\%) and chronic diarrhea (67.85\%) (Table III).

The most relevant findings in the chronic abdominal pain group $(n=29)$ were jejunal and ileal ulcerations, and aphtas suggestive of Crohn's disease (7 patients), duodenal ulcers (2 patients), nonspecific enteropathy (1 patient), and non-bleeding jejunal angiodysplasia (1 patient).
In the chronic diarrhea group $(\mathrm{n}=33)$, lesions suggestive of small bowel Crohn's disease were observed in 19 patients $(56.6 \%)$, and two patients showed findings of nonspecific enteropathy. Several jejunal and ileal nodular lesions with a red periphery and white centre (Fig. 4) were seen in a patient. The findings of a later enteroscopy, together with the histological revision of a specimen from a previous cholecystectomy, made us think of an intestinal ganglioneuromyomatosis. No abnormal findings were detected in 5 patients, and 6 patients only showed findings of little clinical relevance (non-erosive esophagitis, gastritis and duodenitis, or lymphangiectasia).

In the OGB group, 2 patients with hematoquezia, 2 with melena and 9 with chronic iron-deficiency anemia were included. One or more potentially bleeding lesions were identified in ten of thirteen patients $(76.9 \%)$. The most frequent findings were vascular malformations $(\mathrm{n}=$ 4 ), as well as aphtas, focal denudations, and ulcers consistent with small bowel Crohn's disease $(n=3)$, duodenal ulcer $(n=1)$, lesions suggestive of congestive enteropathy $(\mathrm{n}=1)$, and an ulcerated ileal stricture, probably caused by NSAIDs.

The staging of a known gastrointestinal tumor was the indication for CE in 4 patients: one with a MALT lymphoma, one with a lymphomatous polyposis (LP), one with a primary small bowel lymphoma (PSBL), and one with a GIST tumor. CE showed a more widespread involvement than was previously known in the patient with PSBL (jejunal implication, not seen in the small bowel follow-through), and demonstrated the persistency of the lesions in this patient after chemotherapy. In the patient with a GIST tumor, CE showed an intestinal mucosa with normal appearance after surgery. In the cases of LP and MALT lymphoma, CE did not detect a more extensive gastrointestinal affectation than already known.

In the group of patients with dyspepsia and chronic intake of NSAIDs, CE detected erosive lesions that were distal to the reach of the gastroscope in 5 out of 7 cases

Table II. Capsule-endoscopic diagnosis according to indication: group 1- chronic diarrea; group 2- abdominal pain; group 3obscure GI bleeding; group 4- dyspepsia in NSAID takers; and group 5- staging for Gl tumor and group 6-controls

\begin{tabular}{|c|c|c|c|c|c|c|c|}
\hline \multirow[t]{2}{*}{ Diagnosis } & \multicolumn{7}{|c|}{ Number of findings $\left(^{*}\right)$} \\
\hline & $\begin{array}{l}\text { Group } 1 \\
(n=33)\end{array}$ & $\begin{array}{l}\text { Group } 2 \\
(n=29)\end{array}$ & $\begin{array}{c}\text { Group } 3 \\
(n=13)\end{array}$ & $\begin{array}{c}\text { Group } 4 \\
(n=7)\end{array}$ & $\begin{array}{c}\text { Group } 5 \\
(n=4)\end{array}$ & $\begin{array}{c}\text { Group } 6 \\
(n=2)\end{array}$ & Total \\
\hline Crohn's disease & 19 & 7 & 3 & 0 & 0 & 0 & 29 \\
\hline Vascular malformations & 0 & 1 & 7 & 0 & 0 & 0 & 8 \\
\hline Intestinal neoplasms & 1 & 0 & 0 & 0 & 4 & 1 & 6 \\
\hline NSAID-enteropathy & 0 & 0 & 1 & 5 & 0 & 0 & 6 \\
\hline Nonspecific enteropathy & 2 & 1 & 1 & 0 & 0 & 0 & 4 \\
\hline Lymphoid nodular hyperplasia & 1 & 1 & 1 & 0 & 0 & 0 & 3 \\
\hline Peptic ulcer & 0 & 2 & 4 & 2 & 0 & 0 & 8 \\
\hline No abnormalities & 5 & 6 & 0 & 0 & 0 & 0 & 11 \\
\hline Other findings (§): & 15 & 16 & 7 & 7 & 1 & 1 & 47 \\
\hline
\end{tabular}

*: the sum of diagnoses in some groups is higher than the number of patients since a patient may have more than one capsule-endoscopic diagnosis

$\S:$ esophagitis, cardial incompetence, esophageal varices, gastritis, hypertensive gastropathy, hypertensive enteropathy, duodenitis and lymphangiectasias 

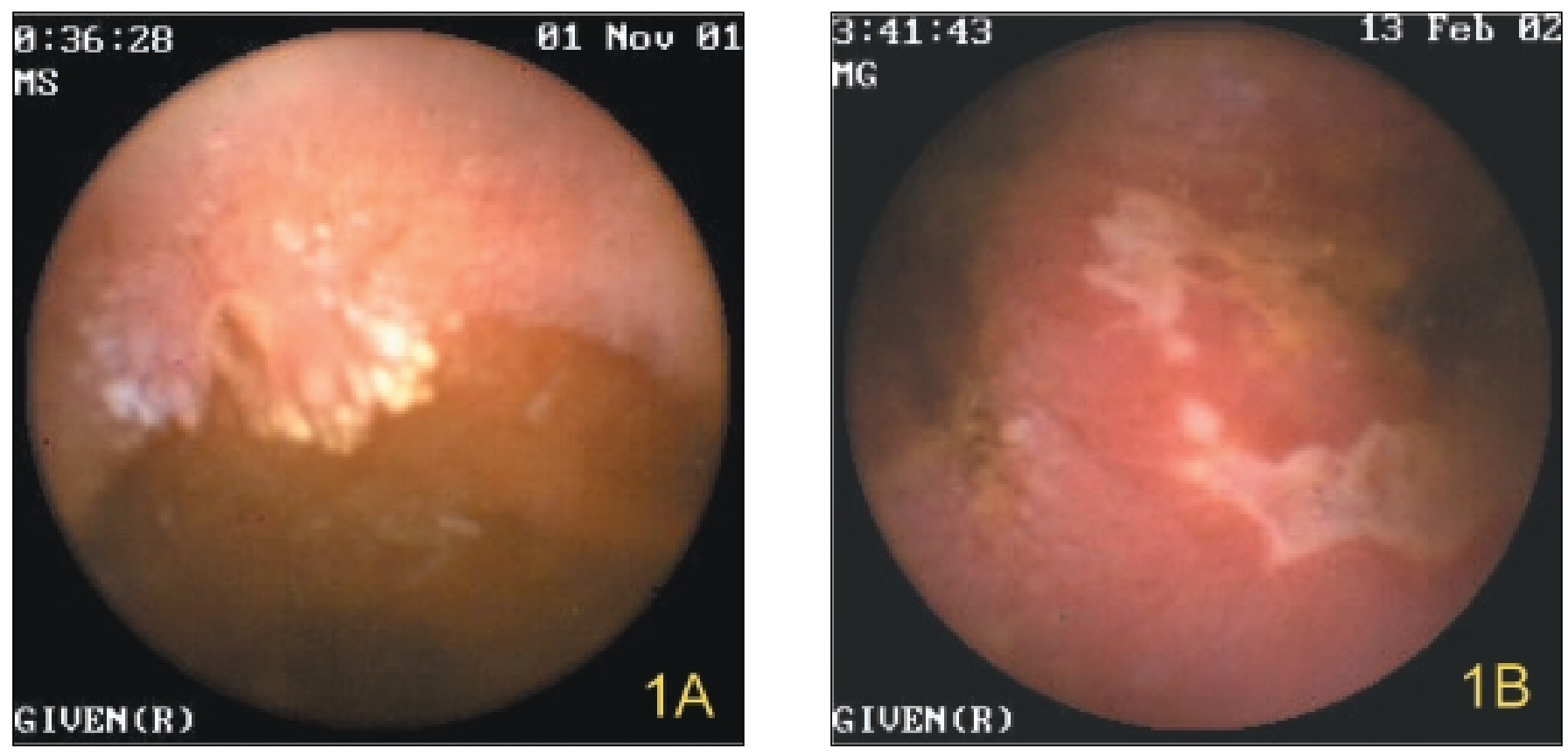

Fig. 1.- Capsule-endoscopic findings compatible with Crohn's disease (1A: fissure and focal denudation; 1B: irregular ulcers in proximal ileon) Hallazgos cápsulo-endoscópicos compatibles con enfermedad de Crohn (1A: fisuración y área denudada; 1B: úlceras irregulares en íleon proximal).
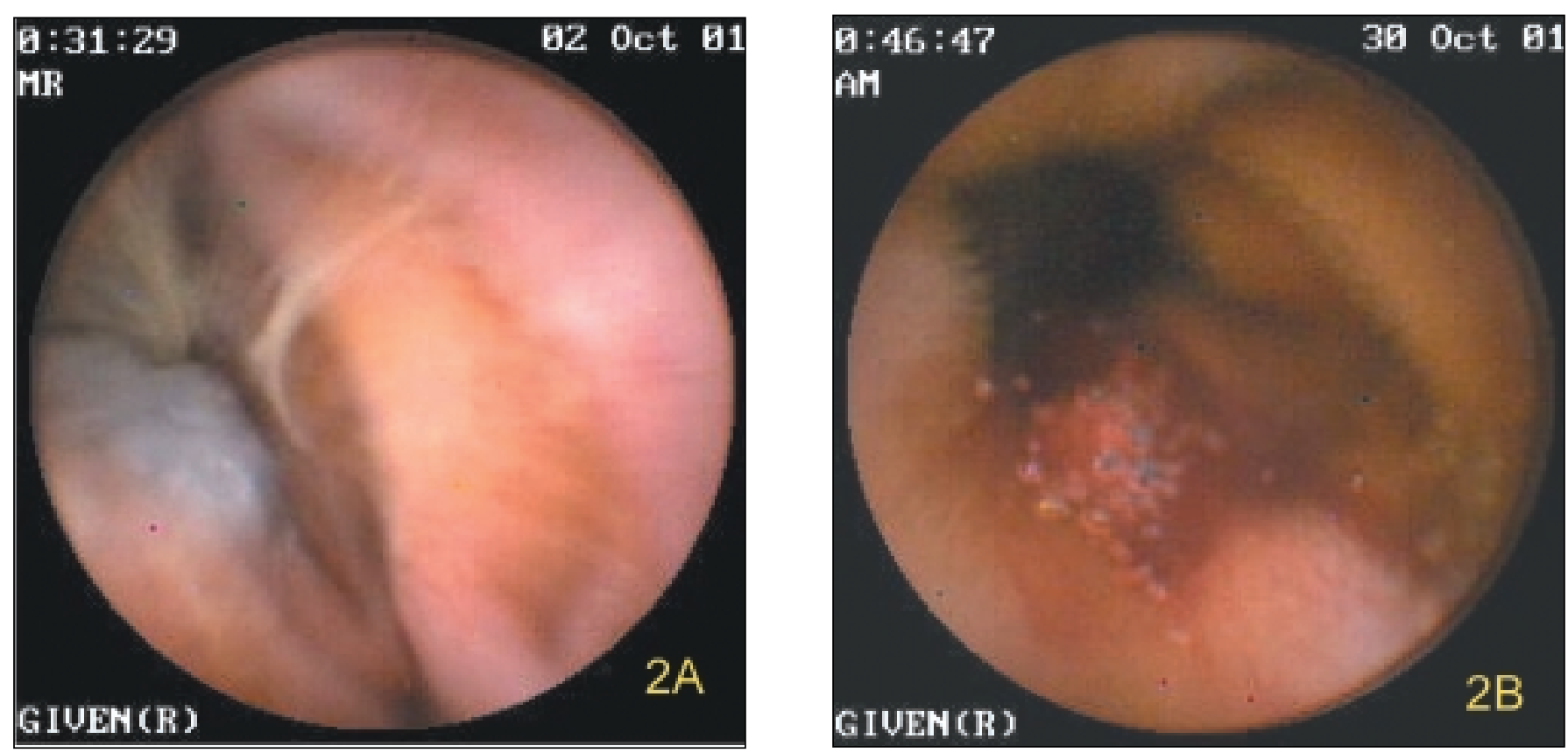

Fig. 2.- Capsule-endoscopic findings in patients with OGB: $2 \mathrm{~A}$ : angioectasia; $2 \mathrm{~B}$ : vascular lesion with active bleeding Hallazgos encontrados en pacientes con hemorragia digestiva de origen oscuro: $2 A$ lago venoso; $2 B$ : lesión vascular con sangrado activo.

$(71.43 \%)$. The two first cases in this series were healthy volunteers in order to check the new technique.

The management of the patient was changed by $\mathrm{CE}$ in 36 out of 88 patients (40.90\%): 29 patients with capsule endoscopy suspected small bowel Crohn's disease in whom conventional treatment was begun, 6 patients with a potentially treatable bleeding lesion, and one patient with PSBL in whom CE demonstrated a lack of response to the chemotherapy applied, and another cytostatic therapy was administered.

Average total transit time was $7.08 \pm 0.99$ in the $92 \mathrm{ex}-$ plorations. The cardia was reached in $1.11 \pm 1.36 \mathrm{minu}-$ tes. Cardial, pyloric and ileoceal valve transit times were $1.11 \pm 1.36,59.86 \pm 63.97$, and $285.79 \pm 87.16$ minutes, 


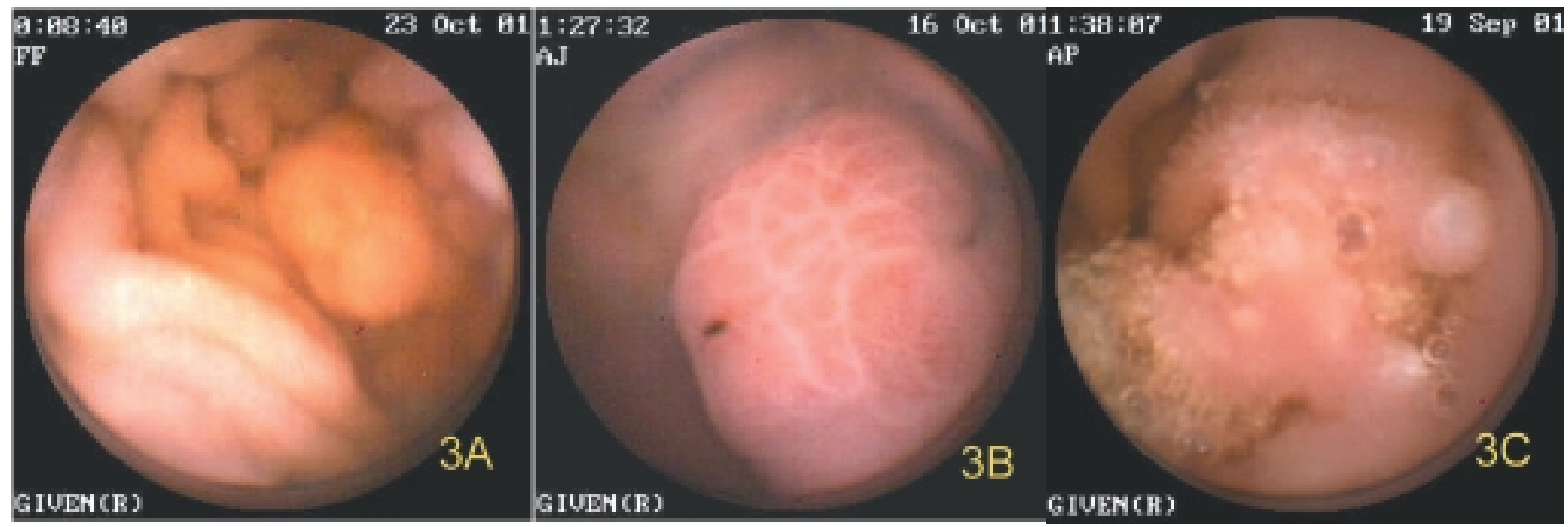

Fig. 3.- Capsule-endoscopic images of different gastrointestinal lymphomas: 3A: duodenal lymphomatous polyposis, 3B: gastric MALT lymphoma, 3C: primary small bowel lymphoma

Imágenes cápsulo-endoscópicas de distintos linfomas gastrointestinales: 3A: poliposis linfomatosa duodenal; 3B: linfoma MALT gástrico; 3C: linfoma intestinal primario.

Table III. Rates of potentially related to the indication capsule-endoscopic findings, according to the various indications

\begin{tabular}{lccc}
\hline & $n$ & $\begin{array}{c}N^{0} \text { patients } \\
\text { with directly } \\
\text { indication- } \\
\text { related capsule- } \\
\text { endoscopic } \\
\text { findings }\end{array}$ & $\begin{array}{c}\text { \% patients } \\
\text { with directly } \\
\text { indication- } \\
\text { related capsule- } \\
\text { endoscopic } \\
\text { findings }\end{array}$ \\
\hline Chronic diarrhea & 33 & 22 & $67.85 \%$ \\
Unexplained abdominal pain & 29 & 10 & $34.48 \%$ \\
Obscure GI bleeding & 13 & 10 & $76.92 \%$ \\
Dyspepsia in NSAID takers & 7 & - & - \\
Staging for GI tumor & 4 & 2 & $50 \%$ \\
Healthy controls & 2 & - & - \\
\hline
\end{tabular}

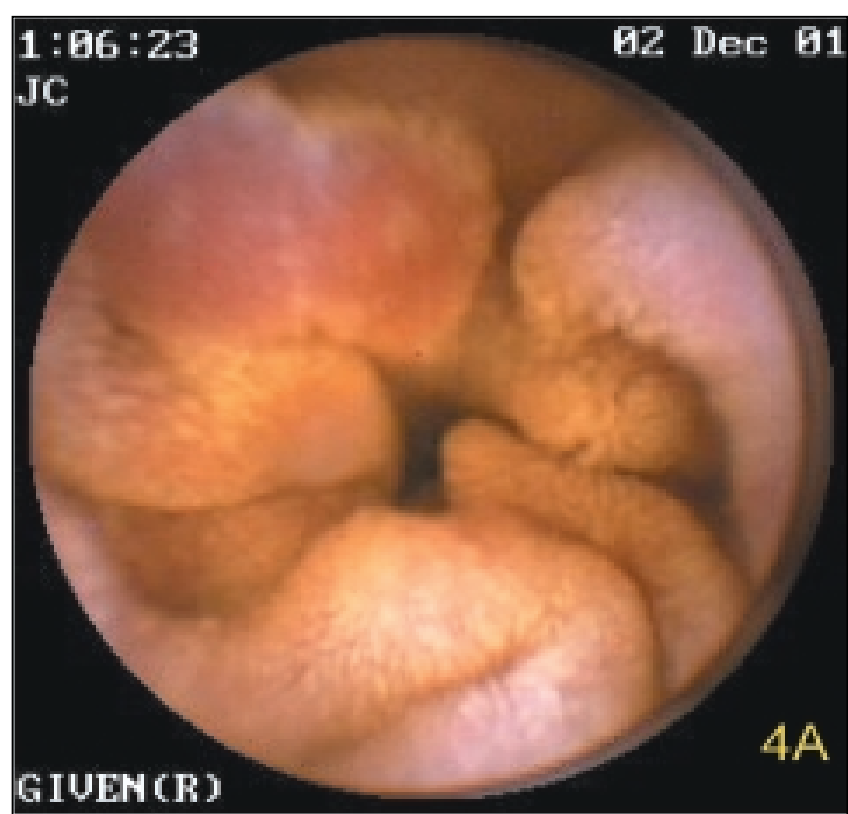

which makes up for an average intestinal transit time of $226.95 \pm 83.32$ minutes. The device could be swallowed without problems by all the patients.

The spontaneous excretion of the capsule happened in all subjets, except in one NSAID user with chronic iron-deficiency anemia. In this case, $\mathrm{CE}$ diagnosed an ileal ulcerated stricture (Fig. 5) that had not been seen in a previous small bowel follow-through, and which caused the retention of the device whitout ill effects. A scheduled laparotomy was carried out three weeks later, where the stricture and the capsule were resected. The histological study showed a focal, subacute inflammation with ulcerations and a non-fibrotic stricture, probably induced by NSAID use. The postoperative course of the patient was uncomplicated, and

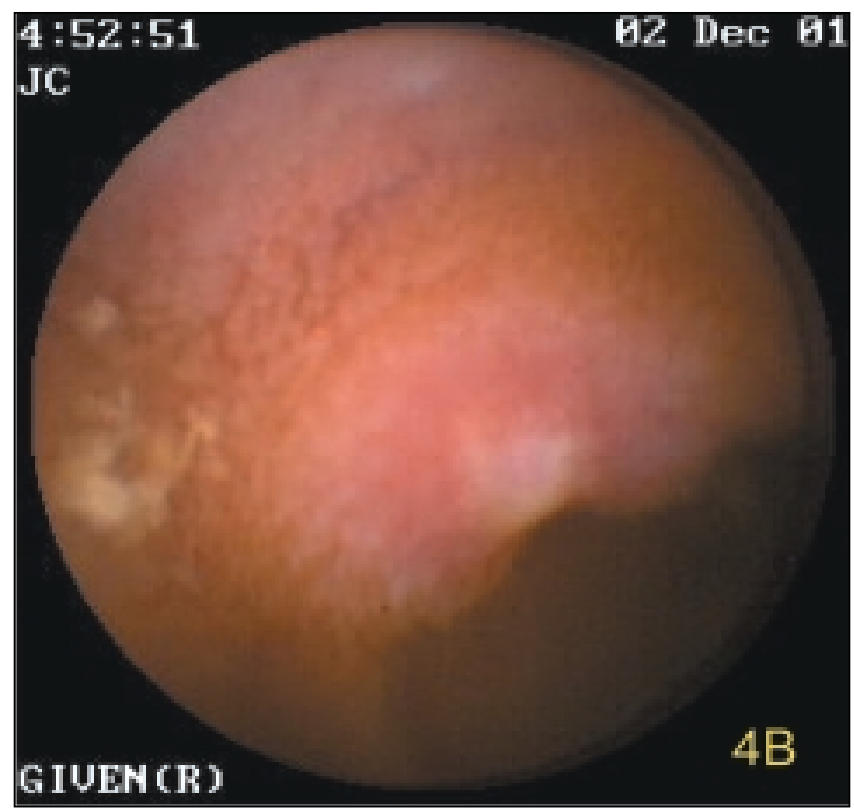

Fig. 4.- $4 \mathrm{~A}$ and $4 \mathrm{~B}$ : capsule-endoscopic findings suggestive of intestinal ganglioneuromyomatosis $4 A$ y $4 B$ : imágenes cápsulo-endoscópicas sugestivas de ganglioneuromiomatosis intestinal. 
after 6 months of follow-up she remains asymptomatic and free of anemia.

No other adverse effects were observed during or after the procedure. The ileocecal valve could be seen in every patient, except in the two cases with delayed gastric emptying, and in the patient with an ileal stricture.

\section{DISCUSSION}

In spite of the radiological and endoscopic advances of the last decades, the study of the small bowel continues to be in many cases a difficult problem in clinical practice. Regarding OGB, conventional radiological, arteriographic and nuclear techniques identify the bleeding lesion in $20-51 \%$ of cases (12-14). PE can reach a diagnosis in 30-50\% of those cases in which conventional explorations had not been conclusive (14-16). However, there is still a percentage of patients in whom only an invasive procedure, such as intraoperative enteroscopy, may be diagnostic. In these difficult cases the accuracy of a new non-invasive and painless technique such as $\mathrm{CE}$ is proposed.

Although numerous abstracts exist, only two studies designed to compare the effectiveness of $\mathrm{CE}$ vs PE in OGB have been published $(17,18)$ to date. In both, CE identified more bleeding lesions than EP, fundamentally at the expense of ileal and distal jejunal lesions, although only in the series by Ell et al. (17) this difference reached statistical significance. In our series $\mathrm{CE}$ also achieved a high diagnostic accuracy $(76.92 \%)$ and, although it was not compared to $\mathrm{PE}$, at least in 5 of 10 patients the potentially bleeding iden-

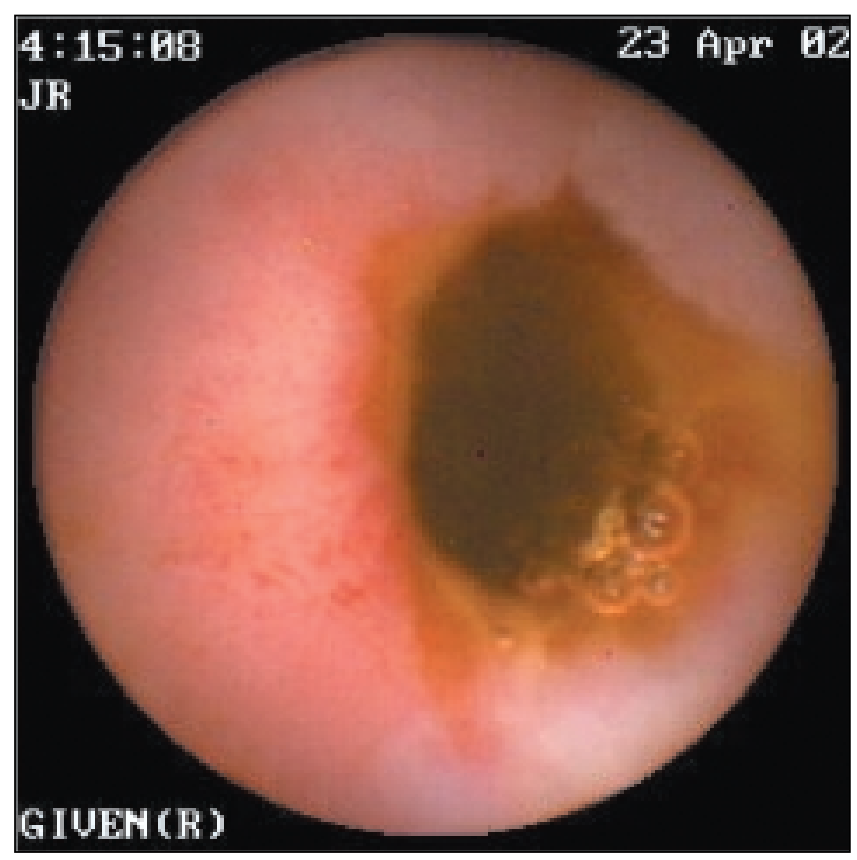

Fig. 5.- Ulcerated ileal stricture in an NSAID taker with iron-deficency anemia

Estenosis ileal ulcerada en paciente consumidora de AINE y con anemia ferropénica. tified lesions were probably beyond the range of PE. These data, although pending confirmation by controlled and randomized trials, seem to endorse the role of CE in OGB (19). In this role it cannot replace PE but may complement it, allowing to select patients with lesions that can be sampled or treated by PE, as well as to rule out the existence of multicentric lesions beyond the reach of PE.

OGB has been the first and more studied indication of $\mathrm{CE}$, but others have been proposed. The accuracy of $\mathrm{CE}$ in these new indications is still to be confirmed. In our series, the group of patients with unexplained chronic pain achieved a low diagnostic yield $(<35 \%)$, so this is a questionable indication for $\mathrm{CE}$ in the absence of other signs or symptoms. On the contrary, potentially-related-tothe-indication findings were observed in $67.85 \%$ of patients with unexplained chronic diarrhea. Obviously, the diagnostic efficacy of $\mathrm{CE}$ in this indication depends on the clinical-biological characteristics of considered patients. Anyway, these preliminary data seem to justify the realization of wider studies to analyze the role of $\mathrm{CE}$ in a subset of patients with chronic diarrhea. In our series, the most frequent findings in the chronic diarrhea group were ulcerations and aphtas suggestive of Crohn's disease (19 of 33 cases). Thus, it is interesting to outline the utility of $\mathrm{CE}$ in cases of Crohn's disease with exclusive jejunal or ileal affectation that could not be diagnosed by means of ileocolonoscopy, small bowel follow-through, or enteroclysis (1). In patients with affectation of the distal jejunum and/or proximal ileon alone, the demonstration of radiological findings and the existence of compatible clinical-biological data are the pillars for diagnosis in Crohn's disease, and it allows the clinician to establish a specific therapy in most cases despite his inability to have histological confirmation from a difficultly accessible area of the gastrointestinal tract (20-25). However, when due to their nature or precocity lesions are not detected by radiological exams, diagnosis and appropriate treatment are delayed from 2 to 4 years by the lack of an appropriate and non-invasive technique allowing this portion of the small bowel to be studied $(1,25-27)$.

CE cannot confirm with certainty the suspicion of Crohn's disease, since it does not allow an anatomo-pathological study, but it can either support or rule out a diagnosis, supposing a valuable additional fact in the clinical and analytic context of these patients in whom obtaining a biopsy of the intestinal lesion would require a surgical procedure (28-31).

The study of tumoral pathology of the small bowel has also been proposed as one of the possible indications of this new technique $(32,33)$, but only some isolated cases have been published to date. In our series, CE allowed to determine the extension of the tumor as well as the response to chemotherapy in one of the cases, with the expected handling implications. The role of CE in small bowel infiltrative tumors would go then from the support of a diagnostic suspicion by the physician, to the performance of the most appropriate sampling technique (34), the staging 
study (35), or the surveillance of response to therapy $(36,37)$. Some authors (33) have outlined the use of CE in the screening of small bowel follow-through in high-risk patients, as is the case for long-term celiac disease that becomes refractory to diet. However, the inability to obtain biopsy samples, as well as the absence of an unequivocal macroscopic appearance of this type of small bowel lymphoma (38), limit this indication at present. Anyway, it seems clear that large, controlled and well-designed studies are needed to establish the true indications of one of the most attractive techniques developed in the last years.

Failed capsule excretion is the most prominent complication of this technique, occurring in approximately $0.5 \%$ of explorations according to the manufacturer (39), and it usually happens in stenotic areas not detected by radiological studies. Surface and form of the capsule make very unusual an obstructive complication $(32,40)$. This way it happened in our patient, a NSAID using woman with two previous small bowel follow-throughs reported as normal. CE demonstrated an ulcerated ileal stricture that impeded the capsule's progression, and that was electively resected three weeks later. So, it seems that the previous realization of a small bowel follow-through is necessary but not enough to rule out an intestinal stricture, what forces the physician to emphasize this eventual complication to his patient before $\mathrm{CE}$, as well as to exclude as candidates for this procedure those patients who are nonsurgical candidates or who refuse to entertain the idea of surgery $(32,40)$.

In conclusion, the present study demonstrates that $\mathrm{CE}$ is a safe technique able to explore the whole small bowel. In spite of its inability to take biopsies, which represents its main limitation, is a procedure that provides valuable information for the handling of patients with small bowel disorders that could not be diagnosed using conventional methods.

\section{REFERENCES}

1. Maglinte DDT, Burney BT, Miller RE, et al. Lesions missed on small bowel follow-through: Analysis and recommendations. Radiology 1982; 144: 737-9.

2. Thoeni RF, Gould RG. Enteroclysis and small bowel series: comparison of radiation dose and examination time. Radiology 1991; 178 : 659-62.

3. Rex DK, Lappas JC, Maglinte DD, et al. Enteroclysis in the evaluation of suspected small intestinal bleeding. Gastroenterology 1989; 97: $58-60$

4. Landi B, Tkoub M, Gaudric M, et al. Diagnostic yield of push-enteroscopy in relation to indication. Gut 1998; 42: 421-5.

5. Lewis B. Enteroscopy. Gastrointest Endosc Clin N Am 2000; 10: 101-16.

6. Swain P. The role of enteroscopy in clinical practice. Gastrointest Endosc Clin N Am 1999; 9: 135-44.

7. Gostout CJ. Sonde enteroscopy. Technique, depth of insertion, and yield of lesions. Gastrointest Endosc Clin N Am 1996: 6: 777-92.

8. Zaman A, Sheppard B, Katon RM, et al. Total perioral intraoperative enteroscopy for obscure GI bleeding using a dedicated push enteros- cope: diagnostic yield and patient outcome. Gastrointest Endosc 1999; 50: 506-10.

9. Iddan G, Meron G, Glukhovsky A, et al. Wireless capsule endoscopy. Nature 2000; 405: 417.

10. Gong F, Swain P, Mills T. Wireless endoscopy. Gastrointest Endosc 2000; 51: 725-9.

11. Appleyard M, Fireman Z, Glukhovsky A, et al. A randomized trial comparing wireless capsule endoscopy with push enteroscopy for the detection of small-bowel lesions. Gastroenterology 2000; 119: 1431-8.

12. Nolan DJ, Traill ZC. The current role of the barium examination of the small intestine. Clin Radiol 1997; 52: 809-20.

13. Rex DK, Lappas JC, Maglinte DD, et al. Enteroclysis in the evaluation of suspected small intetinal bleeding. Gastroenterology 1989; 97 : 58-60.

14. Zuckerman GR, Prakash C, Askim MP, et al. AGA technical review on the evaluation and management of occult and obscure gastrointestinal bleeding. Gastroenterology 2000; 118: 201-21.

15. Hayat M, Axon ATR, O'Mahony S. Diagnostic yield and effect on clinical outcomes of push enteroscopy in suspected small-bowel bleeding. Endoscopy 2000; 32: 369-72.

16. Lewis BS. Small intestinal bleeding. Gastroenterol Clin N Am 1994; 231: 67-91.

17. Ell C, Remke S, May A, et al. The first prospective controlled trial comparing wireless capsule endoscopy with push entroscopy in chronic gastrointestinal bleeding. Endoscopy 2002; 34: 685-9.

18. Lewis BS, Swain P. Capsule endoscopy in the evaluation of patients with suspected small intestinal bleeding: Results of a pilot study. Gastrointest Endosc 2002; 56: 349-53.

19. Caunedo Álvarez A, Rodríguez-Téllez M, Barroso Relinque N, et al. Papel de la cápsula endoscópica en el paciente con hemorragia digestiva de origen oscuro. Rev Esp Enferm Dig 2002; 94: 482-8.

20. Kornbluth A, Sachar DB, Salomon P. Crohn's disease. In: Feldman M, Scharschmidt BF and Sleisenger MH, eds. Sleisenger and Fosdtran's gastrointestinal and liver disease: Pathophysiology / diagnosis / management. Philadelphia: WB Saunders Company, 1998. p. 1708-34.

21. Moum B, Ekbom A, Vatn MH, et al. Inflammatory bowel disease: reevaluation of the diagnosis in a prospective population based study in south eastern Norway. Gut 1997; 40: 328-32.

22. Admans H, Whorwell PJ, Wright R, et al. Diagnosis of Crohn's disease. Dig Dis Sci 1980; 25: 911-5.

23. Lennard-Jones JE. Classification of inflammatory bowel disease. Scand J Gastroenterol 1989; 24 (Supl. 170): 2-6.

24. Horton KM, Jones B, Fishman EK. Imaging of the inflammatory bowel disease. In: Kirsner JB, ed. Inflammatory bowel disease. Philadelphia: WB Saunders Company, 2000. p. 479-502.

25. Su C, Lichtenstein GR. Diagnosis of Crohn's disease: A wolf in sheep's clothing? Am J Gastroenterol 2000; 95: 3345-50.

26. Gay G, Delmotte JS. Enteroscopy in small intestinal inflammatory disorders. Gastrointest Endosc Clin N Am 1999; 9: 115-23.

27. Lescut D, Vanco D, Bonniere P, et al. Perioperative endoscopy for the whole small bowel in Crohn's disease. Gut 1993; 34: 647-9.

28. Rodríguez-Téllez M, Caunedo Álvarez A, Carmona I, García-Montes JM, Pellicer FJ, Herrerías JM. Diagnostic utility of capsule endoscopy in non-confirmed Crohn's disease. Endoscopy 2002; 34 (Supl. II) A70.

29. Fireman Z, Machjina E, Kopelman Y et al. Diagnosing small bowel Crohn's disease with wireless capsule enteroscopy. Gastroenterology 2002; 122 (Supl.): A329.

30. Eliakim R, Fisher D, Suissa A, et al. Wireless capsule video endoscopy is a superior tool compared to barium follow through and entero CT in patientes with suspected Crohn's disease. Gastroenterology 2002; 122 (Supl.): A329.

31. Mascarenhas-Saravia M, Lopes L, Mascarenhas-Saravia A. Wireless capsule endoscopy is aplicable in diagnosis and monitoring of small bowel Crohn's disease. Gut 2002; 51 (Supl. III): A69.

32. Cave DR. Wireless video capsule endoscopy. Clin Persp Gastroenterol 2002; 5: 203-7.

33. Caunedo A, Rodríguez-Téllez, Barroso N, et al. Capsuloendoscopia: La última frontera. Revis Gastroenterol 2002; 4: 1-13.

34. Lopes L, Mascarenhas-Saravia M. Retrospective analysis of cases of small bowel tumors detected by capsule endoscopy. Endoscopy 2002; 34 (Supl.): A91. 
35. Caunedo A, Jiménez-Sáenz, Romero R, et al. The role of capsule endoscopy in the assessment of gastrointestinal lymphomas. Proceedings of the First Given Imaging Conference on Capsule Endoscopy, Rome, Italy, May 17-19, 2002. Rahash Printing: Haifa, Israel: 2002. p 75 .

36. Jiménez-Sáenz M, Caunedo A, Rodríguez-Téllez M, et al. Capsule endoscopy in the surveillanceof patients with primary small bowel lymphoma (case report). Proceedings of the First Given Imaging Conference on Capsule Endoscopy, Rome, Italy, May 17-19, 2002. Rahash Printing: Haifa, Israel. 2002. p. 137.
37. Levinthal G, Burke C, Santis J, et al. Detection of small bowel polyps in a patient with a previously resected small bowel adenocarcinoma: A case report. Proceedings of the First Given Imaging Conference on Capsule Endoscopy, Rome, Italy, May 17-19, 2002. Rahash Printing: Haifa, Israel, 2002. p. 25

38. Olds G, McLoughlin R, O`Morian C, et al. Celiac disease for the endoscopist. Gastrointest Endosc 2002; 56: 407-15.

39. Datos de archivo, Given Imaging Ltd.

40. Faigel DO, Fennerty MB. "Cutting the cord" for capsule endoscopy. Gastroenterology 2002; 132: 1385-937.

\title{
Utilidad de la cápsula endoscópica en pacientes con sospecha de patología de intestino delgado
}

\author{
A. Caunedo, M. Rodríguez-Téllez, J. M. García-Montes, B. J. Gómez-Rodríguez, J. Guerrero', \\ J. M. Herrerías Jr, F. Pellicer y J. M. Herrerías
}

Servicio de Aparato Digestivo. Hospital Universitario Virgen Macarena. Sevilla. ${ }^{1}$ Unidad de Aparato Digestivo. Hospital Civil del INSALUD. Ceuta

\section{RESUMEN}

Objetivo: estudiar la utilidad y seguridad de la cápsula endoscópica como prueba diagnóstica en distintas patologías de intestino delgado.

Diseño: análisis retrospectivo de una serie de casos.

Material y métodos: entre agosto de 2001 y agosto de 2002 se realizaron 92 cápsulo-endoscopias a 88 pacientes (53H/39M, edad: 43,87 $\pm 16,78)$. Las indicaciones fueron: diarrea crónica $(n=33)$; dolor abdominal no filiado $(n=29)$; hemorragia digestiva de origen oscuro o anemia ferropénica $(n=13)$; molestias abdominales en pacientes consumidores de AINE $(n=$ 7); estudio de extensión de tumores gastrointestinales $(n=4)$; y controles asintomáticos $(n=2)$. Todos los pacientes fueron sometidos previamente a tránsito intestinal, gastroscopia y colonoscopia, cuyos hallazgos no fueron concluyentes para el diagnóstico.

Resultados: los hallazgos relevantes más frecuentemente encontrados fueron ulceraciones y aftas yeyunoileales (29 pacientes), malformaciones vasculares (13 pacientes) y neoplasias intestinales (6 pacientes). Los grupos con mayor tasa de hallazgos relacionados con la indicación fueron el de hemorragia digestiva de origen oscuro $(76,92 \%)$ y el de diarrea crónica $(67,85 \%)$, mostrando el grupo de pacientes con dolor abdominal el porcentaje más bajo $(34,48 \%)$. En el $40,90 \%$ de casos $(36 / 88)$ se cambió directamente la estrategia terapéutica del paciente a la luz de los resultados capsuloendoscópicos. La única complicación observada consistió en la falta de excreción de una de las cápsulas por la existencia de una estenosis ulcerada no conocida.

Conclusiones: la cápsula endoscópica es una técnica segura y capaz de estudiar el intestino delgado en su totalidad, suponiendo una valiosa herramienta para el manejo de pacientes con clínica sugestiva de patología intestinal.
Palabras clave: Cápsula endoscópica. Hemorragia digestiva de origen oscuro. Enteroscopia. Enteroclisis. Diarrea crónica. Dolor abdominal.

\section{INTRODUCCIÓN}

Desde el comienzo de los exámenes endoscópicos, la ciencia médica ha pretendido obtener una visualización directa de todo el tracto digestivo, si bien el estudio endoscópico del intestino delgado permanecía esquivo debido a su gran longitud y a la compleja configuración de sus múltiples asas. El tránsito intestinal, la exploración más comúnmente utilizada, no puede detectar las lesiones planas, tales como la angiodisplasia, ni las lesiones mucosas pequeñas (1). Algunos artículos han demostrado que la enteroclisis es una técnica más precisa que el tránsito convencional, aunque esta diferencia no parece ser muy relevante a nivel clínico cuando se compara con un tránsito intestinal bien realizado $(2,3)$. Por otra parte, la enteroclisis precisa de un radiólogo experimentado, es incómoda para el paciente y requiere sedación. Además se trata de una técnica que supone mayor irradicación para el paciente y un mayor consumo de tiempo y recursos (1-3).

La enteroscopia por pulsión (EP) puede diagnosticar lesiones mucosas sutiles, tomar biopsias y realizar proce- 
dimientos terapéuticos, sin embargo su alcance se limita a una parte del intestino delgado, habitualmente entre 50 y 120 centímetros del yeyuno proximal (4-6). Por otra parte, la técnica sólo está disponible en centros especializados, es incómoda para el paciente, tiene que ser realizada con sedación profunda, sus resultados dependen en parte de la experiencia del endoscopista, y las complicaciones aparecen más frecuentemente que en la endoscopia digestiva alta (EDA), particularmente cuando se utiliza sobretubo (4-6). Por su parte, la enteroscopia lastrada se ha empleado durante varios años para alcanzar áreas más distales del intestino delgado. Sin embargo, incluso con este método raramente se lograba una completa visualización completa del intestino, y varias zonas de la mucosa no podían explorarse debido al movimiento, en ocasiones incontrolado, de la sonda durante la retirada (7). Esta técnica requiere también de mucho tiempo, es molesta e incapaz de tomar biopsias o realizar terapéutica, razones por las cuales el procedimiento se ha abandonado en la práctica clínica. Por último, la enteroscopia intraoperatoria, aunque con alto porcentaje de eficacia diagnóstica y terapéutica, es una técnica más invasiva, asociada a una mayor tasa de complicaciones (8).

Los recientes avances en la robótica y la miniaturización han permitido el desarrollo de la cápsula endoscópica (CE), un pequeño dispositivo que puede ser deglutido por el paciente y, de manera indolora y no invasiva, es capaz de proporcionar imágenes de todo el intestino delgado (9-11). El propósito de este estudio fue exponer nuestra experiencia de un año con la CE, así como analizar la utilidad de la misma como herramienta diagnóstica en diferentes patologías intestinales.

\section{PACIENTES Y MÉTODO}

Pacientes: desde el 30 de agosto de 2001 hasta el 30 de agosto de 2002, se realizaron 92 CE a 88 pacientes con diferentes signos y síntomas digestivos. Treinta y un pacientes eran mujeres y 53 hombres, con una media de edad de 43,87 $\pm 16,78$ (rango: 8 -74) años. Las indicaciones para realizar la CE fueron: diarrea crónica (grupo 1, $\mathrm{n}=33$ ); dolor abdominal no explicado (grupo 2; $\mathrm{n}=29$ ); hemorragia digestiva de origen oscuro (HDOO) o anemia ferropénica (grupo 3; n=13); molestias abdominales en un grupo de pacientes consumidores de AINE participantes en un estudio prospectivo que evalúa lesiones gastrointestinales (grupo 4; n=7); estudio de extensión de tumores (grupo $5 ; \mathrm{n}=4$ ); y controles asintomáticos (grupo $6 ; n=2)$ (Tabla I).

Todos los pacientes fueron sometidos previamente a EDA y colonoscopia, cuyos hallazgos no fueron concluyentes para la confirmación diagnóstica de la sospecha inicial. Con la intención de descartar lesiones inflamatorias o estenóticas se realizó al menos un tránsito intestinal en los sujetos incluidos. Se contraindicó el uso de la cápsula en los pacientes que no pudieran deglutir el disposi-
Tabla I. Características epidemiológicas de los pacientes explorados mediante cápsulo-endoscopia, según su indicación

\begin{tabular}{lrrc}
\hline & $n$ & Mujeres & Edad \\
\hline Diarrea crónica & 33 & 11 & $36,19 \pm 17,41$ \\
Dolor abdominal no filiado & 29 & 13 & $47,24 \pm 13,72$ \\
HDOO & 13 & 7 & $49,54 \pm 22,99$ \\
Dispepsia en consumidores de AINE & 7 & 7 & $50,8 \pm 13,01$ \\
Estudio de extensión de tumores GI & 4 & 1 & $48,67 \pm 7,94$ \\
Controles sanos & 2 & 0 & $55,5 \pm 2,12$ \\
Total & 88 & 39 & $43,87 \pm 16,78$ \\
\hline
\end{tabular}

GI: gastrointestinal; HDOO: hemorragia digestiva de origen oscuro.

tivo, en los pacientes con marcapasos o cualquier otro aparato electromédico implantado, las mujeres embarazadas y aquellos pacientes que no eran candidatos quirúrgicos o que rechazaban la idea de intervenirse en caso de obstrucción debida a la cápsula. Todos los sujetos fueron informados de la técnica, verbalmente y por escrito, firmando el consentimiento informado antes de realizar el procedimiento.

Método: se utilizó un cápsula endoscópica de 11 x 26 mm (M2A ${ }^{\mathrm{TM}}$ Given Imaging ${ }^{\circledR}$, Yoqneam, Israel) que contiene el chip de una cámara a color capaz de tomar dos fotografías por segundo, una fuente de luz blanca, una lente de distancia focal corta, un transmisor de radiofrecuencia en la banda UHF, una antena y dos baterías. El desplazamiento del dispositivo a través del tubo digestivo sigue los movimientos peristálticos intestinales fisiológicos y no necesita insuflación de aire. Ocho sensores colocados en la pared abdominal recogen las fotografías transmitidas. Estas imágenes son grabadas en un sistema Holter que porta el paciente en un cinturón alrededor de la cintura durante las 7-8 horas de duración de las baterías que incorpora la cápsula. Una vez terminada la prueba, las imágenes recogidas en el Holter se procesan en un ordenador, que permitirá su análisis y selección utilizando el programa RAPID ${ }^{\mathrm{TM}}$.

Técnica: los pacientes deben someterse a ayuno de sólidos y líquidos al menos en las 8 horas anteriores a la CE. El sujeto podrá tomar su medicación habitual pero siempre antes de las 8 horas previas al procedimiento, evitándose el consumo de fármacos que pudieran retrasar el vaciamiento gástrico. En primer lugar se colocan los 8 sensores en el abdomen del paciente, así como el cinturón con el sistema Holter alrededor de su cintura. Tras retirar la cápsula de su envoltorio y comprobar que la luz azul de la grabadora parpadea, la cápsula es ingerida por el paciente con un vaso de agua. La capsuloendoscopia se realiza de forma ambulatoria, debiendo el paciente permanecer en ayunas las dos horas siguientes. Pasado ese tiempo puede beber líquidos y tras 4 horas se le permite tomar un ligero aperitivo sólido y la medicación habitual. A todos los sujetos se les indica que deben contactar con el médico inmediatamente si notan dolor, molestias abdominales, náuseas o vómitos durante el procedimiento. Se les advierte igualmente que no deben acercarse a ninguna 
fuente de campos electromagnéticos intensa (tales como aparatos de resonancia magnética), hasta que evidencien la expulsión de la cápsula por las heces. Tras 8 horas, los pacientes regresan a la consulta para retirar los sensores y el Holter, el cual es conectado al ordenador para volcar la información que será posteriormente procesada y revisada en el programa RAPID ${ }^{\mathrm{TM}}$. Dicho programa permite la visualización de las fotografías a varias velocidades, tiene la posibilidad de detener y rebobinar las imágenes, así como de localizar puntualmente el recorrido de la cápsula.

Análisis estadístico: los resultados se muestran en porcentajes o valores medios \pm desviación estándar, según cada caso.

\section{RESULTADOS}

La CE pudo ser realizada en los 88 pacientes del estudio. En 4 casos se realizó una segunda exploración. En dos pacientes con neoplasia gastrointestinal (linfoma intestinal primario y tumor estromal gastrointestinal) (GIST) fueron revisados mediante una segunda CE tras su tratamiento específico (quimioterapia y cirugía, respectivamente). En un paciente con HDOO y vaciamiento gástrico enlentecido la cápsula permaneció en la cavidad gástrica las 8 horas de duración de la batería, siendo excretada 5 días más tarde, por lo que se le realizó una nueva $C E$ tras la administración de un procinético 8 días más tarde, en la que sí pudo estudiarse el intestino delgado completo. En otro caso la CE no transmitió imágenes una vez alcanzado el estómago, administrándose una nueva cápsula el día siguiente sin problema técnico alguno.

En 11 pacientes la CE no mostró anormalidades. Entre los hallazgos más frecuentes (Tabla II) destacan aquellos sugestivos de enfermedad de Crohn (áreas denudadas con fisuraciones, ulceraciones y aftas; 29 pacientes) (Fig. 1), malformaciones vasculares (angiomas o angiodisplasias; 8 pacientes) (Fig. 2), neoplasias intestinales (pólipos, lin- fomas, tumor GIST; 6 pacientes) (Fig. 3), lesiones sugestivas de ser secundarias a la toma de AINE (erosiones, úlceras, estenosis; 6 pacientes), hiperplasia nodular linfoide (3 pacientes), linfangiectasias o pequeños quilomas (10 pacientes), y enteropatía de la hipertensión portal (1 paciente). Se observaron erosiones o pequeñas ulceraciones gastroduodenales en 8 pacientes, en 4 casos habían sido ya advertidas en EDA anteriores y en otros 4 casos (los 4 con HDOO como indicación) fueron diagnosticadas mediante la CE. En 4 pacientes se apreciaron lesiones intestinales sutiles, del tipo de edema, discretas denudaciones o eritemas que fueron calificados como enteropatía inespecífica. Otros hallazgos, ya vistos en las EDA previas, fueron lesiones compatibles con esofagitis (25 pacientes), varices esofágicas (1 paciente), gastritis y duodenitis no erosiva (35 pacientes) y gastropatía congestiva (3 pacientes). Los grupos en el que la CE mostró un mayor porcentaje de pacientes con hallazgos potencialmente relacionados con la indicación fueron la $\operatorname{HDOO}(84,6 \%)$ y la diarrea crónica $(67,85 \%)$ (Tabla III).

En el grupo de pacientes con dolor abdominal no filiado (29 pacientes) los hallazgos patológicos más destacables fueron ulceraciones y aftas yeyuno-ileales sugestivas de enfermedad de Crohn (7 pacientes), úlceras duodenales ( 2 pacientes), enteropatía inespecífica (1 paciente), y angiodisplasia yeyunal no sangrante (1 paciente).

El grupo de pacientes con diarrea crónica no filiada (33 pacientes) presentó un 57,6\% (19 pacientes) de casos con imágenes compatibles con enfermedad de Crohn con afectación exclusiva yeyuno-ileal, así como dos casos de enteropatía inespecífica. En un paciente se objetivó la existencia de numerosas lesiones nodulares yeyuno-ileales, con aspecto en diana, blanquecinas en su centro y eritematosas en su periferia, que impresionaban de origen subcutáneo (Fig. 4). Se realizó una enteroscopia, que junto con la revisión histológica de la pieza de colecistectomía del paciente (intervenido meses antes) hicieron pensar en la existencia de una ganglioneuromiomatosis intestinal. Cinco pacientes presentaron una cápsulo-en-

Tabla II. Diagnósticos capsuloendoscópicos según la indicación considerada: grupo 1- diarrea crónica; grupo 2- dolor abdominal; grupo 3- hemorragia digestiva de origen oscuro; grupo 4- consumidores de AINE con dispepsia; grupo 5- extensión tumoral y grupo 6- controles

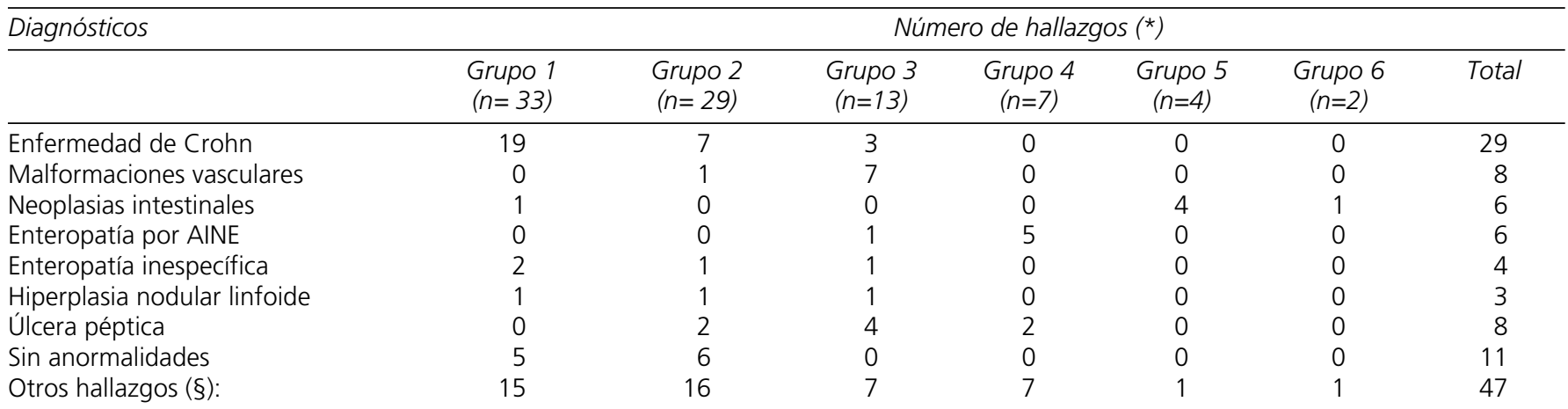

*: la suma de diagnósticos en algunos grupos es mayor al número de enfermos ya que un paciente puede tener más de un diagnóstico capsuloendoscópico.

$\S$ : esofagitis, incompetencia cardial, varices esofágicas, gastritis, gastropatía de la hipertensión portal, enteropatía de la hipertensión portal, duodenitis y linfangiectasias. 
Tabla III. Porcentaje de hallazgos capsuloendoscópicos potencialmente relacionados con la sospecha diagnóstica inicial, según las distintas indicaciones

\begin{tabular}{|c|c|c|c|}
\hline & $n$ & $\begin{array}{l}\text { No pacientes } \\
\text { con hallazgos } \\
\text { directamente } \\
\text { relacionados con } \\
\text { la sospecha } \\
\text { diagnóstica }\end{array}$ & $\begin{array}{l}\text { \% pacientes } \\
\text { con hallazgos } \\
\text { directamente } \\
\text { relacionados con } \\
\text { la sospecha } \\
\text { diagnóstica }\end{array}$ \\
\hline Diarrea crónica & 33 & 22 & $67,85 \%$ \\
\hline Dolor abdominal no filiado & 29 & 10 & $34,48 \%$ \\
\hline HDOO & 13 & 10 & $76,92 \%$ \\
\hline $\begin{array}{l}\text { Dispepsia en consumidores de } \\
\text { AINE }\end{array}$ & 7 & - & - \\
\hline $\begin{array}{l}\text { Estudio de extensión de tumores } \\
\text { Gl }\end{array}$ & 4 & 2 & $50 \%$ \\
\hline Controles sanos & 2 & - & - \\
\hline
\end{tabular}

doscopia dentro de la normalidad, y en 6 casos se encontraron tan sólo hallazgos de menor relevancia clínica (esofagitis, gastritis, duodenitis o linfangiectasias).

Entre los 13 pacientes en los que se indicó la CE por HDOO, 2 presentaban rectorragia, 2 melenas, y 9 anemia ferropénica crónica. En 10 de los 13 pacientes (76,9\%) estudiados se identificaron una o varias lesiones potencialmente sangrantes. Las lesiones más frecuentemente encontradas fueron las malformaciones vasculares (angiodisplasias/ angiomas): 4 pacientes; y la enfermedad de Crohn yeyuno-ileal: 3 pacientes; además de un caso de estenosis yeyunal ulcerada probablemente secundaria al consumo de AINE; una úlcera duodenal en un paciente (como único hallazgo) y un enfermo con cirrosis hepática con lesiones sugestivas de enteropatía congestiva.

El estudio de extensión de tumores gastrointestinales ya conocidos fue la indicación en 4 pacientes: uno de ellos con linfoma MALT, uno con poliposis linfomatosa (PL), uno con linfoma primario del intestino delgado (LPID) y una paciente con tumor GIST. La CE evidenció una afectación más extensa de la conocida mediante técnicas convencionales en el paciente con LPID (afectación yeyunal además de la duodeno-ileal observada en el tránsito intestinal), y demostró la persistencia de afectación yeyunal en dicho paciente tras la quimioterapia. En la paciente con el tumor GIST, la técnica mostró una mucosa de aspecto normal tras la resección quirúrgica de la neoplasia. En el caso de los pacientes con PL y linfoma MALT, la CE descartó la existencia de afectación intestinal más extensa.

En el grupo de pacientes con consumo crónico de AINE y dispepsia, el estudio mediante CE demostró lesiones erosivas más allá del alcance del gastroscopio en 5 de 7 casos $(71,43 \%)$. Los dos primeros casos de la serie lo constituyeron dos voluntarios sanos, con la intención de comprobar el perfecto funcionamiento del sistema.

Los hallazgos en la CE decidieron o apoyaron una actitud terapéutica concreta en 36 de los 88 pacientes (40,90\%): 29 pacientes con diagnóstico cápsulo-endoscópico de enfermedad de Crohn en los que se inició la tera- pia convencional, 6 pacientes en los que se identificó una lesión sangrante potencialmente tratable (en el paciente con enteropatía de la hipertensión portal se adoptó una actitud conservadora), y 1 paciente con linfoma intestinal tratado mediante quimioterapia y en la que la CE evidenció la falta de respuesta a dicho tratamiento, lo que apoyó la indicación de una nueva terapia citostática.

La media del tiempo total de transmisión fue de 7,08 \pm 0,99 horas en nuestra serie, alcanzándose el cardias en $1,11 \pm 1,36$ minutos, el píloro en 59,86 minutos y la válvula ileocecal en $285,79 \pm 87,16$ minutos, lo que supuso un tiempo de tránsito en intestino delgado de 226,95 \pm 83,32 minutos. Ningún paciente presentó problemas en la deglución de la cápsula. En todos los casos la cápsula fue excretada espontáneamente, a excepción de una paciente consumidora de AINE y con anemia ferropénica severa en la que la CE demostró la existencia de una estenosis ulcerada en íleon (Fig. 5), y que no había sido evidenciada en dos tránsitos intestinales baritados realizados con anterioridad. La cápsula no pudo pasar la citada estenosis, si bien la paciente no presentó clínica obstructiva. La paciente fue intervenida regladamente a las pocas semanas para filiar y tratar su estenosis, realizándose resección del segmento estenótico. El estudio histológico confirmó el diagnóstico de estenosis ileal ulcerada probablemente secundaria a la toma de AINE, emitido tras la capsuloendoscopia, permaneciendo la paciente asintomática tras 6 meses de seguimiento. No se observaron otros efectos adversos o complicaciones relacionados con la técnica. En todos los casos el tiempo de emisión permitió el estudio de la válvula ileocecal, excepto en los dos casos ya señalados de vaciamiento gástrico enlentecido y estenosis ileal ulcerada.

\section{DISCUSIÓN}

A pesar de los avances radiológicos y sobre todo endoscópicos de las últimos décadas, el estudio del intestino delgado continúa siendo en muchos casos un difícil problema en la práctica clínica. En lo referente a la HDOO, las técnicas radiológicas y nucleares habituales, incluyendo la arteriografía, logran la identificación de la lesión sangrante entre el $20-51 \%$ de los casos, según las series (12-14). La enteroscopia por pulsión puede llegar a un diagnóstico en un 30-50\% de esos casos no aclarados tras las técnicas de estudio habituales (14-16). Sin embargo, queda aún un porcentaje de pacientes en los que tan sólo una técnica agresiva como la enteroscopia intraoperatoria parece ser la única solución. En este contexto es donde se plantea la utilidad de una nueva técnica no agresiva e indolora como es la CE.

Aunque existen numerosos estudios comunicados a congresos, hasta la fecha tan sólo se han publicado dos estudios $(17,18)$ diseñados para comparar la eficacia de la CE frente a la EP en la HDOO. En ambos, la CE identificó más lesiones sangrantes que la EP, fundamentalmente a expensas de 
lesiones ileales, si bien sólo en el trabajo de Ell y cols. (17) dicha diferencia alcanzó la significación estadística. En nuestra serie la CE logró también una alta eficacia diagnóstica $(76,92 \%)$ y aunque no fue comparada con enteroscopia, al menos en 5 de los 10 pacientes en los que se identificaron lesiones potencialmente sangrantes, estas se encontraban muy probablemente fuera del alcance de la enteroscopia por pulsión. Estos datos, aunque pendientes de confirmación por series controladas y randomizadas de mayor tamaño parecen avalar el papel de la CE en la HDOO (19). Dicho papel, aunque está aún por precisar, no puede pasar por sustituir en absoluto a la enteroscopia, sino más bien por complementarla, permitiendo en ocasiones seleccionar los pacientes susceptibles de biopsia o tratamiento enteroscópico, o bien descartando la existencia de lesiones multicéntricas más allá del alcance del enteroscopio.

Si bien la HDOO ha sido la primera y más estudiada indicación de la $\mathrm{CE}$, se han propuesto otras en las cuales la eficacia de la nueva técnica está aún por determinar. En nuestra serie, el grupo de pacientes con dolor crónico no filiado obtuvo un bajo rendimiento diagnóstico (inferior al $35 \%$ ), por lo que es cuestionable dicha indicación en ausencia de otros signos o síntomas. Por el contrario, obtuvimos hallazgos potencialmente relacionados con la indicación en el $67,85 \%$ de los pacientes con diarrea crónica no filiada. Obviamente, la eficacia diagnóstica en esta indicación dependerá de las características concretas clínico-biológicas del grupo de pacientes en cuestión, si bien estos datos preliminares parecen justificar la realización de estudios más amplios que analicen el papel de la $\mathrm{CE}$ en determinados subgrupos de pacientes con diarrea crónica. En nuestra serie, los hallazgos más encontrados en el grupo de diarrea crónica fueron ulceraciones y aftas sugestivas de enfermedad de Crohn (19 de 33 casos). En este sentido, resulta interesante plantear la utilidad que la CE puede tener en los casos de enfermedad de Crohn con afectación yeyuno-ileal y que no pueden ser diagnosticados mediante ileocolonoscopia, tránsito intestinal o enteroclisis (1). En los pacientes con afectación exclusiva de yeyuno distal y/o íleon proximal, la demostración de hallazgos radiológicos y la existencia de datos clínico-biológicos compatibles son los pilares del diagnóstico de enfermedad de Crohn, llevando a instaurar la terapia específica en la mayoría de los casos, a pesar de no poder contar con el estudio histológico de una porción poco accesible del tracto digestivo (20-25). Sin embargo, cuando por la naturaleza o precocidad de las lesiones estas no son detectadas por la radiología, el diagnóstico y adecuado tratamiento se ve demorado entre 2 y 4 años por la falta de una técnica de imagen adecuada y no invasiva que permita estudiar dicha porción del intestino (1,25-27). La $\mathrm{CE}$, si bien no puede confirmar con certeza la sospecha de enfermedad de Crohn, ya que no permite el estudio anátomo-patológico, sí puede apoyar o descartar el diag- nóstico, suponiendo un valioso dato adicional en el contexto clínico y analítico de estos pacientes en los que la toma de biopsias requeriría un acto quirúrgico (28-31).

El estudio de la patología tumoral de intestino delgado ha sido también propuesta como una de las posibles indicaciones de esta nueva técnica $(32,33)$, si bien sólo existen hasta la fecha algunos casos aislados publicados sobre el estudio mediante CE de estos enfermos. En nuestra serie, la técnica permitió determinar la extensión del tumor así como la ausencia de respuesta tras quimioterapia en uno de los casos, con las implicaciones de manejo que ello supuso. El papel de la CE en los tumores infiltrativos del intestino delgado iría pues desde el apoyo de una sospecha diagnóstica que llevaría a la realización de la técnica más oportuna para la toma de biopsias (34) hasta el estudio de extensión (35), o el control de la respuesta a la terapia instaurada $(36,37)$. En esta misma línea, algunos autores (33) han planteado la utilización de la CE en el cribado de tumores intestinales en pacientes de alto riesgo, como sucede en la celiaquía de larga evolución que se hace refractaria al tratamiento. Sin embargo, la incapacidad de tomar biopsias, así como la ausencia de un aspecto macroscópico inequívoco del linfoma intestinal que pueden llegar a desarrollar estos pacientes (38), limitan por el momento esta indicación. En cualquier caso, parece claro que se precisan estudios amplios, controlados y bien diseñados que nos permitan sentar las verdaderas indicaciones de una de las técnicas más atractivas desarrolladas en los últimos años.

La ausencia de excreción de la $\mathrm{CE}$ es la complicación más destacable de la técnica, aproximadamente un 0,5\% de las exploraciones según el fabricante (39), y suele darse en zonas estenóticas no detectadas mediante radiología, si bien la superficie y forma de la cápsula hacen que habitualmente no se produzca cuadro obstructivo $(32,40)$. De este modo sucedió en una paciente de nuestra serie, consumidora de AINE, y en la que dos tránsitos intestinales previos no evidenciaron una estenosis ileal ulcerada, que fue resecada regladamente semanas después. Parece pues que la realización previa a la $\mathrm{CE}$ de un tránsito intestinal es necesaria pero no suficiente para descartar una estenosis intestinal, lo que obliga a recalcar esta eventual complicación al paciente antes de la técnica, así como a excluir como candidatos a la misma a aquellos enfermos que no quieran o no puedan someterse a una intervención en el caso de una impactación $(32,40)$.

A la luz de los datos de nuestra serie, podemos concluir que la cápsula endoscópica es una técnica segura y capaz de estudiar el intestino delgado en su totalidad. A pesar de su incapacidad para tomar biopsias, lo que supone su principal limitación, se trata de un procedimiento que puede aportar una valiosa información para el manejo de pacientes con patología de intestino delgado que no han podido ser diagnosticados por métodos convencionales. 